\title{
ACTIVITY OF MASTER CRAFTSMEN IN LATVIA
}

Liga Jankova ${ }^{1}$, Andrejs Lazdins ${ }^{2}$, Anita Auzina ${ }^{3}$

1,2,3 Latvia University of Life Sciences and Technologies

\begin{abstract}
In the regions of Latvia, there is still a huge under-researched and unused resource - crafts. Its products are represented by small entrepreneurs who operate according to the Law on Commercial Activity. Accounting of craftsmen's data is performed by the Latvian Chamber of Crafts (LCC). Crafts is not separated as a statistical unit in Latvia. Demand for crafts manufactured products is significant; the supply is wide as well. Crafts is a valuable cultural, social and historical asset, which encourages creation of income and economic development, especially in rural districts and at the regional level. Crafts as a cultural and social asset requires a development strategy. Market globalization reduces the geographical distance of the consumers and the producers of the crafts products, and it is directly linked with the use of internet technology. The present research summarizes crafts activity in Latvia, analyses the use of marketing instruments by master craftsmen. The results revealed the professional experience of the master craftsmen - 26 years on average, which indicates to a serious problem of master craftsmen's aging and the insufficient master craftsmen's ability to apply modern technology to promote their products and services.
\end{abstract}

Key words: regional development, crafts, indicators.

JEL code: R12

\section{Introduction}

At present the notion (handi) craftsman has become topical. In Latvia, the activity of a craftsman is regulated by the law "On Craftsmanship" (Amatniecibas, 1993). In the National Development Plan of Latvia (NAP, 2012), the unique culture and creative human capital resources are emphasised as factors of competitive non-agricultural entrepreneurship. The development of these factors is determined in two directions, within which the tasks to be executed are related to support for traditional crafts, developing products and services based on the material and nonmaterial cultural heritage. The responsible institutions have been determined: the Ministry of Agriculture (MA), the Ministry of Culture (MC), the Ministry of Education and Science (MoES), municipalities, social partners, non-governmental organizations. There are few publications and little research on the development and evaluation of crafts in Latvia, but research could facilitate benefits both at the municipality and at the regional level. The research novelty - research on the economic significance of crafts has been conducted in Latvia, and it attempts to explain the expression of traditional cultures as valuable cultural, social and historical assets that encourage the economic development of the country, but the evaluation of the activity of craftsmen in regions has not been performed yet.

Research goal: comparison of crafts activity in the regions of Latvia.

To attain the research goal, the following tasks were executed: 1 ) the essence of crafts was clarified; 2) the factors influencing crafts were compared.

\section{Materials and methods}

The research was both qualitative and quantitative, summarizing information about 155 craftsmen in Latvia. The number of respondents comprises $24 \%$ of females and $76 \%$ of males. The respondents were divided based on their experience of activity, distinguishing the following groups: 1-10 years, 11-20 years, 21-30 years, 31-65 years. As a result, the current crafts situation and product promotion were characterized. Based on the obtained data, conclusions and recommendations were developed. The data that characterise the crafts sector and that are 
published on the site of the Latvian Chamber of Crafts (LCC) were used as the informative basis to perform the research.

Research methods: content analysis of the literature and internet sources was performed to prepare this publication; the selected data were processed and interpreted applying statistical data processing and interpretation methods. Year 2017 was the analysed period.

Research limitations: data about the activity of craftsmen in Latvia were analysed.

\section{Research results and discussion}

Summarizing the opinions of the world researchers about the importance of crafts in the national, regional and local development the various meanings and opinions are marked:

- in the rural territories of Asia, it offers the opportunities of the least provided population to obtain livelihood, which is especially true regarding women and children. Those market segments are not aimed at becoming international enterprises. They represent a respective production alternative, especially developing manual handicraft SMEs, which happens in relation with certain requirements regarding demand (Divandari, 2017, Ammar, 2017);

- as a result, the overall rural development takes place, especially regarding sustainable preservation of the environment and mastery of crafts (Bilgin at al., 2011; Mir, 2014, Mustafa, 2011);

- it is a way to attract tourists in order to obtain income (Lukich at al, 2015);

- state support is necessary - development and implementation of the crafts policy in order to protect the viability of the industry and its development for future generations (Dutton, 1983);

- the creative power of the people is transformed into raw materials and goods; crafts forms simple industries without complicated methods; it can be considered a source of income and an additional job for people (Divandari, 2017);

- in crafts, nature and culture are complementary categories. They cannot be considered separately. The identity of public culture is linked with the natural environment in which it is developing (Hadgich, 2005).

In Latvia, there exists research on the economic significance of crafts, explaining the expression of traditional cultures as valuable cultural, social and historical assets that facilitate the development of income and economic development, especially in rural districts and at the regional level. Facilitation of the expression of local cultures enhances the increase of culture-related economic activities, for example renewing food traditions and producing handicraft products, including crafted ones (Jeroscenkova at al., 2015).

The crafts activities in Latvia are regulated by a number of normative documents: law "On Craftsmanship" (1993), Regulations of the Cabinet of Ministers (CM) No. 762 "Regulations on trades in which a person's professional activity shall be considered crafts" (Noteikumi, 2009), which define crafts as a person's professional activity in trades, the list of which has been approved by the Cabinet of Ministers, and which state the limitations for receiving the titles 'craftsman' and 'master craftsman' (Par Amatniecibu, 1993). The Regulations list 7 groups, which comprise 269 trades (Fig. 1.). 


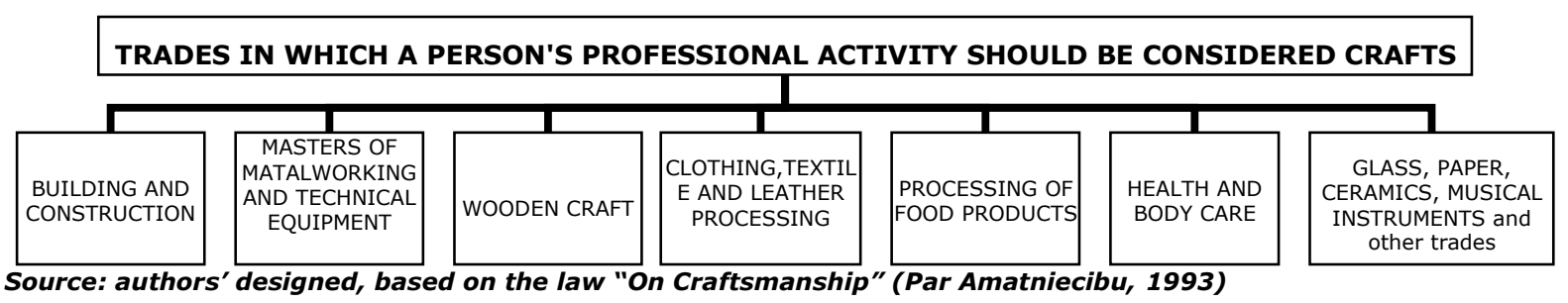

\section{Fig. 1. Groups of crafts trades in Latvia in 2017}

In Latvia, territorial and industry crafts organizations and the Latvian Chamber of Crafts (LCC) are professional crafts organizations. Professional crafts organizations develop programmes for crafts education and qualification requirements. Summarizing the available information of the LCC about the territorial organizations, three of them are indicated: "Talsu Amatnieku biedriba" (Talsi Craftsmen's Society) in Kurzeme region, "Jelgavas Amatnieku biedriba" (Jelgava Craftsmen's Society) in Zemgale region and "Daugavpils Amatnieku biedriba" (Daugavpils Craftsmen's Society) in Latgale region. Only the latter one ("Daugavpils Amatnieku biedriba" in Latgale region) is active. It offers cooperation with 7 trade coordinators of Daugavpils Craftsmen's Society. In the LCC webpage section of territorial organizations, there is no wider information available on the events related to the activities of crafts production. Searching in the indicated regions for crafts related activities, it can be concluded that the LCC is not the only organization which craftsmen can join to establish cooperative sales places. The strength of the LCC is awarding certification, which is not obligatory for craftsmen, but which, as any standard, approves of stronger competition. To provide substantiated recommendations for improving the operation of the LCC, additional research is required.

5. Academically educated master craftsman - vocational university college.

4. Master craftsman - obtains education in a master craftsman's school or a crafts centre, and it is certified by a Master craftsman's diploma - a qualification certifying document that approves the ability to organize and execute professional work and to manage a crafts enterprise.

3. Craftsman - has obtained education in a vocational secondary school or in crafts centres, according to the education programme.

2. Apprentice - has obtained education in crafts (apprentices) schools - has passed the apprentice's test in the amount included in the vocational training and testing programme and has been awarded a crafts golden diploma.

1. Trainee obtains education in a vocational enterprise or training institution, has signed a study contract. Enterprises approved by the LCC or the territorial industry or a crafts society have the right to train.

Source: authors' designed, based on the LCC

\section{Fig. 2. Craftsmen's qualification levels in Latvia in 2017}

The LCC represents the professional and social interests of craftsmen, facilitates the development of crafts, organizes training in trade, develops programmes for awarding the title of an apprentice, a craftsman and a master craftsman, assigns the craftsman's qualification, registers trade masters, apprentices and trainees, accounts crafts enterprises and master's workshops, and 
maintains the crafts register. Latvia has developed a system how one can become a craftsman via reaching various degrees of crafts (Fig. 2.).

To certify the craftsman's qualification, the Craftsman's Map has been designed. It is a certification document issued for a particular time by the Latvian Chamber of Crafts. The LCC includes a Crafts Council which executes the process of master craftsman's qualification and certification approval. In order to become a master craftsman in Latvia, a master craftsman's profile has been developed, which comprises basic requirements for the candidate's education: secondary education; 8 years of work experience in the suitable position, including training in vocational education ( 4 years). Candidates with higher education in the profession need 3 years of practical work experience; a passed qualification examination in the trade according to the "Requirements for Testing Master Craftsmen" as approved by the LCC and according to a testing programme developed by the respective professional organization of the LCC and approved by the MoES and the LCC Crafts Council.

To record data on craftsmen, the LCC has designed an electronic database. Crafts enterprises, master craftsmen, apprentices and trainees, as well as other information related to craftsmen and crafts is accounted. The database is maintained by the LCC. Craftsman as a profession is included in the profession classifier of Latvia (LM, 2017). Craftsman as a statistical category is not accounted in Latvia. Therefore, a problem exists that many craftsmen have not registered their activity in the LCC database. The available database reflects only part of the craftsmen's activity in Latvia. It is impossible to separate the economic contribution of master craftsmen to evaluate the effectiveness of their activity. In normative documents a crafts enterprise is defined as entrepreneurship dealing with crafts.

As of 1992 a conception of vocational education has been designed in Latvia. It states that vocational education should be inherited so that it would correspond to the interests of both the population and the economy. The document is 26 years old, which indicates to a serious loss of its topicality. In the section of legal documents on the LCC site one can find a number of more documents adopted in 1990-ies. The research authors did not conduct in-depth research of those documents to prove that they are outdated, but it is clear that over time any document requires both modern definitions and revision of processes. The development of crafts requires working out and implementation of a new policy in order to protect the viability of the industry and its development for future generations. Strategic development documents related to crafts activity are not available now, which leads to a conclusion that crafts as an element of culture, social identity and national sustainability is insignificant at present although the NDP 2014-2020 (NAP, 2012) emphasizes the unique culture and human capital resources as factors of competitive entrepreneurship.

Using the LCH database, the professional experience of master craftsmen was grouped with the purpose to compare it with average and group indicators.

As it can be seen in Table 1 summarized indicators, on average a trade master has 26 years of professional experience. The oldest 7 trade masters have an experience of 52-66 years, which indicates to a very rich professional experience. The group of 21-65 years possesses the largest proportion of experience as in total it comprises $65 \%$ of all trade masters. The indicators approve that trade masters as heirs of crafts are aging, and in the future it can cause extinction of some professions and losing the cultural identity. 


\section{Indicators of the professional experience and marketing activities of craftsmen in Latvia in 2017}

\begin{tabular}{|c|c|c|c|c|c|c|c|c|c|c|}
\hline $\begin{array}{c}\text { Groups of master } \\
\text { craftsmen' } \\
\text { professional } \\
\text { experience }\end{array}$ & $\begin{array}{l}\frac{1}{0} \\
\frac{\partial}{\varepsilon} \\
\frac{\Sigma}{z} \\
z\end{array}$ & 竞 & 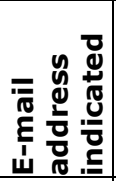 & 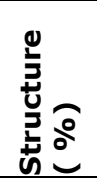 & 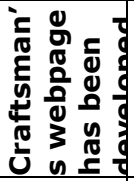 & 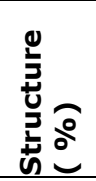 & 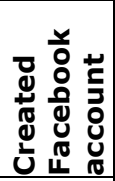 & 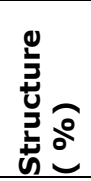 & 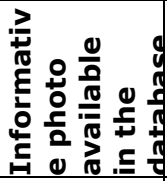 & 站 \\
\hline 1-10 years & 19 & 12 & 12 & 8 & 3 & 2 & 0 & 0 & 2 & 1 \\
\hline $11-20$ years & 30 & 19 & 28 & 18 & 6 & 4 & 2 & 1 & 7 & 5 \\
\hline $21-30$ years & 55 & 35 & 49 & 32 & 17 & 11 & 2 & 1 & 10 & 6 \\
\hline 31-65 years & 44 & 28 & 39 & 25 & 7 & 5 & 0 & 0 & 11 & 7 \\
\hline Not indicated & 7 & 5 & 27 & 17 & 121 & 79 & 151 & 97 & 125 & 81 \\
\hline Total & 155 & 100 & 155 & 100 & 155 & 100 & 155 & 100 & 155 & 100 \\
\hline
\end{tabular}

Source: LCC database and authors' calculations

Craftsmen should join together to establish strong societies. As the information summarized in Figure 2 indicates, master craftsmen concentrate in Riga (52\%). In other regions of Latvia, they are distributed like this: $17 \%$ in Vidzeme, $13 \%$ in Kurzeme, and from 3-7 \% in the other regions. The geographically fragmented location of master craftsmen does not allow them to be active members of societies and reduces their ability to participate in societies. According to the LCC data, the Society of Latvian Chimney-sweeps is the strongest as it comprises 34 chimney-sweeps of Riga.

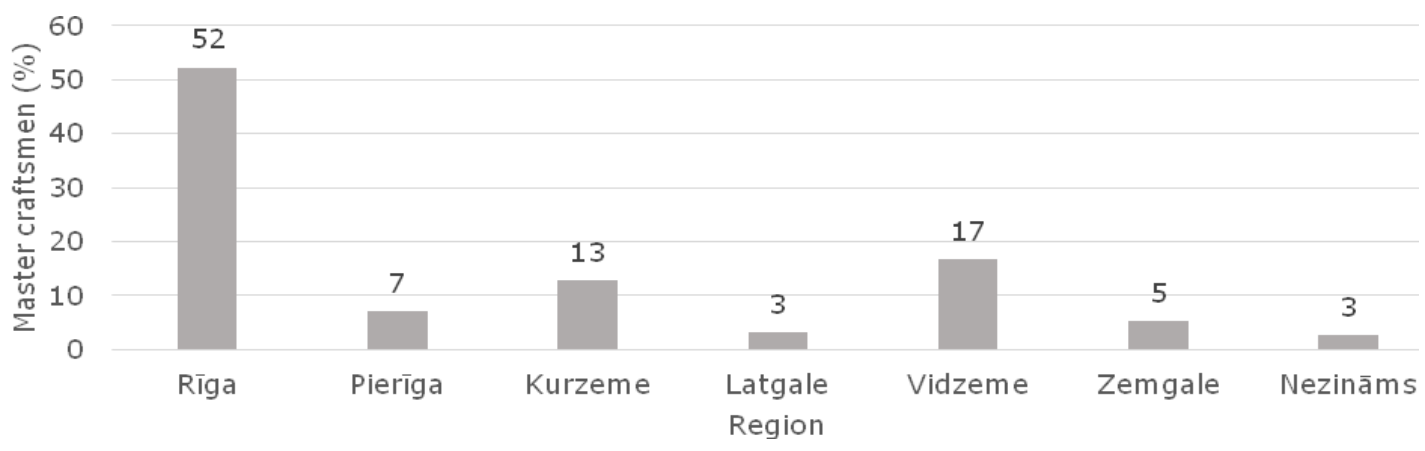

Source: Authors' designed, based on the LCC database

Fig. 2. Regional distribution of master craftsmen in Latvia in 2018

Nowadays, the market globalization reduces geographical distance between the craftsman and the client; the internet and social networks have even more encouraged market globalization. As emphasized in the guidelines developed by the International Market Centre "Marketing of Crafts and Visual arts - Practical Significance of Intellectual property", craftsmen can compete in the market with a qualitative product, a different brand and effective marketing. Nowadays effective marketing is related to the use of the internet environment to promote a product (Marketing, 2003). Such indicators of marketing activities as whether the craftsman has created an email un publishes it in the database, whether the craftsman has designed a webpage, has created and uses a Facebook account, has added his/her photo and the photos of the product and the production process were compared. As Table 1 depicts, indicators of marketing activities are very low. $17 \%$ of the craftsmen have not created and indicated their email addresses, $79 \%$ do not possess a website, $97 \%$ do not own a crafts activity related Facebook account, $81 \%$ of the craftsmen have not entered photos in the LCC database, but photos would enhance clients' interest about the craftsman's product or service. 
Modern technology allows anyone to analyse not only marketing activities, but also the content of the information carrier - craftsmen's websites. The SEO (Search Engine Optimization) tool, which determines the webpage content, was applied to analyse the websites via performing the audit of key words, the analysis of competition; determining the strategic words or primary words; promotion of the webpage in Google search ensuring "TOP" level (first page); development of a promotion strategy and an implementation plan. In total 30 craftsmen's webpages were evaluated, which is $19.3 \%$ of the total number of respondents. Evaluating the "TOP" level of the webpages, $4(13.3 \%)$ webpages appear on the first page of Google search, which is a very good indicator (average top 3 place in Latvia). 4 (13.3\%) webpages cannot be found among the first 100 pages, which purports that the sites designed by master craftsmen perform a formal function and are not aimed at the client. The other webpages, which are found between the first and the hundredth level, constitute $73.6 \%$ in total.

Evaluating the key words of the craftsmen's webpages and comparing the product or the offered service, it can be stated that in 9 cases (30\%) the key words have been properly determined. In the other cases a consequent action in providing information cannot be observed. Analysing the headings of the webpages, it can be concluded that they correspond to overall accepted standards only in one case. It has to be taken into consideration that headings of the webpage sections are reflected in search results, they provide a short description of the topic. Key words must appear in the webpage headings.

Evaluating the webpage content, it was observed that in 5 cases (16\%) a product, a service or a producer's or service provider's description was developed, which is a very poor indicator.

Evaluating the total of webpages, the situation is bad. Factors that can create such a situation is craftsmen's work in a narrow niche market where clients are well known; craftsmen's poor knowledge about communication, especially in the internet environment, which is approved by the low number of webpages; the weak cooperation among the respondents (craftsmen) about the types of crafts. As it can be observed in the analysis, cooperation exists between separate categories of craftsmen - for example chimney-sweeps, whose number of webpages is one of the best among the respondents. Communication problems in crafts have not been studied and are difficult to be researched because craft is very fragmented, it does not possess a development strategy.

\section{Conclusions, proposals, recommendations}

1) Latvia has a developed basis of normative documents for craftsmen's activity and the status of a craftsman has been defined. A strategy for the development of crafts in Latvia has not been designed.

2) Latvia has developed an organizational structure that supports, educates and certifies craftsmen - territorial and industry organizations of crafts and the Latvian Chamber of Crafts (LCC). A system how one can become a craftsman, achieving various degrees, has been developed in Latvia.

3) For crafts to develop, design and implementation of a policy is required in order to protect the industry's viability and its development for future generations. Crafts as an element of culture, social identity and national sustainability is unimportant in Latvia at present.

4) To account the master craftsmen, a database has been developed, but the statistical record and evaluation of the craftsmen's activity in the total data record of the Central Statistical Bureau 
has not been performed. That does not allow anyone to analyse the economic benefits, particularly regarding master craftsmen.

5) Master craftsmen in Latvia as carriers of crafts skills are aging, and in the future it may cause extinction of some professions and losing the cultural identity.

6) Master craftsmen in Latvia insufficiently use information technology and social networks to promote their products and services, which reduces the product recognition and master craftsmen's economic benefits. The webpages created by master craftsmen perform a formal function and are not aimed at the customer.

7) The LCC as a provider of crafts traditions needs to design a development strategy and an action plan for implementing the strategy.

8) The LCC as a craftsmen's consultative and educational organization needs to educate craftsmen to apply IT in product promotion.

9) Crafts activities in Latvia should be continued to be studied in-depth.

\section{Bibliography}

1. Ammar F. (2017). The Growth Factors of Tunisian Handicraft Small and Medium-sized Enterprises (SMEs): towards an integration. International Journal of Technology Management \& Sustainable Development. Vol. 16 Issue 3, p229-248. Retrieved: http://web.a.ebscohost.com/ehost/results?vid=0\&sid=ded8ccbe-678e$493 \mathrm{c}-8 \mathrm{a} 85-$

3eda8ceb10b1 \%40sessionmgr4010\&bquery=handicraft\&bdata=JmRiPWE5aCZkYj1sMGgmZGI9ZTAwMHh3d yZkYj1ubGViayZkYj1lcmljJmRiPWhIdiZkYj04Z2gmZGI9aHhoJmRiPWhjaCZkYj1seGgmZGI9ZjVoJmRiPWNtZW RtJmRiPW5maCZkYj10cmgmZGxpMD1OTCZkbHYwPVkmZGxkMD1ubGViayZOeXBIPTAmc2I0ZT1laG9zdC1saX ZI. Access: 15.01.2018.

2. Bilgin, M. H., Demir, E., Lau, M. C. K., Kin-Man To, C., Zhang, Z. M. (2011). The Turkish handmade carpet industry: analysis in comparison with select Asian countries. Journal of the Textile Institute, 102 (6), p514526.

3. Celvedis majražošana (b.g.) (Home produced guide). Izdevejs: SIA "Latvijas Lauku konsultaciju un izglitibas centrs. Ozolnieku novads, LV-3018.

Retrieved: https://www.zm.gov.Iv/public/ck/files/PVD/celvedis_majrazosana.pdf. Access:15.01.2018.

4. Divandari, J., Danaeinia, A., Izadi, p. (2017). Analysis of the Role of Handicraft Production in Rural Sustainable Development: A Case of Sar Aqa Seyyed, Chaharmahal and Bakhtiari Province. Journal of History, Culture \& Art Research / Tarih Kültür ve Sanat Arastirmalari Dergisi. Special issue, Vol. 6 Issue 1 , p549-565.

5. Dutton, R. W. [1983]. Handicrafts in Oman and their role in rural community development. Geoforum, 14 (3), p341-352.

6. Hadgich, O. (2005). Kulturni turizam. (Cultural tourism). Novi Sad: Univerzitet u Novom Sadu, Prirodnomatematički fakultet, Departman za geografiju, turizam i hotelijerstvo.

7. Jeroscenkova, L., Rivza, B., Kruzmetra, M., Melece,, L., Spaks, A., Artisiusevski, M. (2015). The value of cultural heritage: the state in Belarys and Latvia. Proceedings of the 25th NJF Congress, Nordic View to Sustainable Rural Development. 2015, p481-488.

8. LM. (2017). LR Labklajibas ministrija. Profesiju klasifikators. ( LV Ministry of Welfare). Classifications of professions. Retrieved: http://www.Im.gov.Iv/. Access: 15.01.2018.

9. Lukich, T., Stojanovich, T., Đerchan, B., Zivkovich, M., Zivkovich, J.(2015). The Geographical Aspects of Traditional Handicrafts in Serbia. European Researcher. Vol. 100 Issue 11, 747-758.

10. Marketing Crafts and Visual Arts: The Role of Intellectual Property (2003). Practical guide; Geneva: ITC/WIPO, p135.

11. Mir, L. , Bhushan, S. (2014). An Analysis of Current Scenario and Contribution of Handicrafts in Indian Economy. Journal of Economics and Sustainable Development, 5(9), p75-78.

12. Mustafa, M. (2011). Potential of Sustaining Handicrafts as a Tourism Product in Jordan. International Journal of Business and Social Science, 2 (2), p145 -152.

13. NAP (2012).Latvijas nacionalais attistibas plans 2014.-2020. (The Latvian National Development Plan 20122020). Retrieved: https://likumi.lv/doc.php?id=253919. Access: 15.01.2018.

14. Noteikumi par amatiem, kuros personas profesionala darbiba ir uzskatama par amatniecibu (The provisions of posts which personal professional activity is considered as crafts). MK noteikumi (Regulations of Minister Cabinet) nr. 762 (14.07.2009.). Retrieved: https://likumi.lv/doc.php?id=194944. Access: 15.01.2018.

15. Par Amatniecibu (Handicrafts Law) (1993). LR likums. Retrieved: https://likumi.lv/doc.php?id=63052. Access: 15.01.2018. 